Pacific Journal of Mathematics

APPROXIMATION PROPERTIES OF POLYNOMIALS WIT 


\title{
APPROXIMATION PROPERTIES OF POLYNOMIALS WITH BOUNDED INTEGER COEFFICIENTS
}

\author{
V. Drobot and S. McDonald
}

For every fixed positive integea $N$, let $\mathscr{P}_{N}$ denote the set of all polynomials $p(x)=\sum a_{i} x^{i}$ where $a_{i}$ is an integer, $\left|a_{i}\right| \leqq N$. For a fixed real number $t$ set $\mathscr{P}_{N}(t)=\left\{p(t): p \in \mathscr{P}_{N}\right\}$.

Theorem 1. Suppose $1<t<N+1$ and $t$ is not a root of map of the polynomials from $\mathscr{P}_{N}$. Then $\mathscr{P}_{N}(t)$ is dense in $R$.

TheOREM 2. If $t$ is an $S$-number then $\mathscr{P}_{N}(t)$ is discrete for every $N$.

1. For every fixed positive integer $N$, let $\mathscr{P}_{N}$ denote the set of all polynomials $p(x)$ with integer coefficients, $p=\sum a_{i} x^{i}$, such that $\left|a_{i}\right| \leqq N$. For a fixed real number $t$ set

$$
\mathscr{P}_{N}(t)=\left\{p(t): p \in \mathscr{P}_{N}\right\} \text {. }
$$

It was shown in [1] that if $N=1, t$ is a number such that $1<t<2$ and $t$ is not a root of any of the polynomials from $\mathscr{P}_{1}$ then the set $\mathscr{P}_{1}(t)$ is dense in the real line. (It is fairly easy to see that if $t \notin(1, N+1), t>0$ than $\mathscr{P}_{N}(t)$ cannot be dense in $\left.\boldsymbol{R}\right)$. At the same time it was shown that $\mathscr{P}_{1}(1 / 2(1+\sqrt{5}))$ is discrete. As far as we know this is the only known example of $N$ and $t \in(1, N+1)$ such that $\mathscr{P}_{N}(t)$ is discrete. In this paper we prove two extentions of these results. The first is a straightforward generalization of [1]:

THEOREM 1. Suppose $1<t<N+1$ and $t$ is not a root of any of the polynomials from $\mathscr{P}_{N}$. Then $\mathscr{P}_{N}(t)$ is dense in $\boldsymbol{R}$.

The second result is more intriguing and has a curious connection with what is known as $P-V$ numbers or $S$-numbers $(P-V$ numbers for Pisot-Vijayaragharan, see [2] for details).

Definition. A number $t>1$ is called a $P-V$ number if it is an algebraic integer and all of its conjugates have absolute value strictly less than 1 .

THEOREM 2. If $t$ is a $P-V$ number then $\mathscr{P}_{N}(t)$ is discrete for every $N$.

It follows, for instance, that $\mathscr{P}_{N}(1 / 2(1+\sqrt{5}))$ is discrete for all $N$, not just $N=1$. 
Let $\|s\|$ denote the distance from $s$ to the nearest integer. A number $\theta$ is said to have property $(\mathrm{P})$ if for some $\lambda>1,\left\|\lambda \theta^{n}\right\| \rightarrow 0$. It is known that every $P-V$ number has property (P). A conjecture is raised in [2] as to whether the converse is true: Is every number with property (P) a $P-V$ number? It is known that every algebraic number with property $(\mathrm{P})$ is a $P-V$ number. Thus the conjecture would be settled if one could show that for every number $t$ having property $(\mathrm{P})$, the set $\mathscr{P}_{N}(t)$ is discrete.

The proof of Theorem 1 is essentially no different from the proof given in [1] for $N=1$. We proceed with the proof of Theorem 2 now.

LEMma 1. Suppose $t>1$ and 0 is an accumulation point of $\mathscr{P}_{N}(t)$. Let $k, m$ be any positive integers. There exists polynomial $p$ of the form $p(x)=x^{m_{1}} f(x), f \in \mathscr{P}_{N}, m_{1}>m$ such that

$$
t^{-k-1} \leqq p(t)<t^{-k}
$$

Proof. Let $r(x)$ be a polynomial in $\mathscr{P}_{N}$ such that

$$
0<r(t)<t^{-k-m_{1}} \text {. }
$$

Let $m_{1}$ be the smallest integer such that

$$
t^{-k-m_{1}-1}<r(t) \text {. }
$$

Then $m_{1}>m$ and $r(t)<t^{-k-m_{1}}$. Thus

$$
t^{-k-1}<t^{m_{1}} r(t) \leqq t^{-k}
$$

Lemma 2. Suppose $t>1$ and 0 is an accumulation point of $\mathscr{P}_{N}(t)$. Then $\mathscr{P}_{N}(t)$ is dense in $\boldsymbol{R}$.

Proof. Let $u>0$ and $\eta>0$ be fixed. Let $k$ be so large that the interval $\left[t^{-k-1}, t^{-k}\right]$ has length less than $\eta$. There is a sequence of polynomials $p_{1}, p_{2}, \cdots$, having no common terms $\alpha_{j} x^{j}$ such that

$$
t^{-k-1}<p_{n}(t) \leqq t^{-k}
$$

This follows by applying Lemma 1 with fixed $k$ and making $m_{1}$ larger and larger. If

$$
q_{m}(t)=p_{1}(t)+\cdots+p_{m}(t)
$$

then $q_{m}(t)>m t^{-k}$, so $q_{m}(t) \rightarrow \infty$. Hence for some $m, q_{m}(t)$ will be

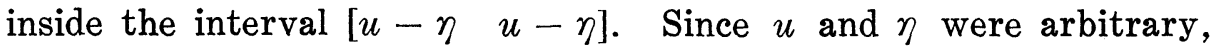
the result follows. 
Proof of Theorem 2. It is enough to show that $\mathscr{P}_{N}(t)$ is not dense for any $N=1,2, \cdots$. Indeed, suppose this is done and assume that $\mathscr{P}_{N_{0}}(t)$ is not discrete. Then clearly $\mathscr{P}_{2 N_{0}}(t)$ has 0 as an accumulation point and by Lemma 2 is dense. To show $\mathscr{P}_{N}(t)$ is not dense for any $N$ we argue as follows. Let

$$
t=t_{1}, t_{2}, \cdots, t_{p}
$$

be all the roots of the irreducible monic polynomial of $t$, and let

$$
\sigma=\max \left\{\left|t_{2}\right|,\left|t_{3}\right|, \cdots,\left|t_{p}\right|\right\}
$$

so that $0<\sigma<1$. For any $k$

$$
t^{k}+t_{2}^{k}+\cdots+t_{p}^{k}
$$

is an integer, hence

$$
\mid t^{k} \text {-integer }\left.|\leqq| t_{2}\right|^{k}+\cdots+\left|t_{p}\right|^{k} \leqq(p-1) \sigma^{k} .
$$

Let $p(x)=\alpha_{0}+\alpha_{1} x+\cdots+\alpha_{j} x^{j}$ be a polynomial in $\mathscr{P}_{N}$. Then

$$
t^{k} p(t)=\sum_{n=0}^{j} \alpha_{n} t^{k+n}
$$

so

$$
\begin{aligned}
\mid t^{k} p(t)-\text { integer } \mid & \leqq \sum_{n=0}^{j}\left|\alpha_{n}\right|(p-1) \sigma^{k+n} \\
& \leqq N(p-1) \frac{\sigma^{k}}{1-\sigma}
\end{aligned}
$$

Choose $k$ so large that the right hand side is less than $1 / 3$. Then

$$
\left|p(t)-\frac{\text { integer }}{t^{k}}\right|<\frac{1}{3} \frac{1}{t^{k}}
$$

or, if the integer is odd

$$
\left|p(t)-1 / 2 \frac{\text { integer }}{t^{k}}\right| \geqq \frac{1}{6} \frac{1}{t^{k}}
$$

for any $p \in \mathscr{P}_{N}$.

\section{REFERENCES}

1. V. Drobot, On sums of powers of a number, Amer. Math. Monthly, 80 (1973), 42-44.

2. R. Salem, Algebraic Numbers and Fourier Analysis, Boston, 1963. 
Received November 10, 1978 and in revised form May 4, 1979.

UNIVERSity of SANTA Clara

SANTA Clara, CA 95053

AND

UNIVERSITY OF CALIFORNIA

Berkeley, CA 94720 


\title{
PACIFIC JOURNAL OF MATHEMATICS
}

\section{EDITORS}

\author{
DoNALD BABBITT (Managing Editor) \\ University of California \\ Los Angeles, CA 90024 \\ HUGo RossI \\ University of Utah \\ Salt Lake City, UT 84112 \\ C. C. MOORE and ANDREW OGG \\ University of California \\ Berkeley, CA 94720
}

J. DugundJI

Department of Mathematics

University of Southern California

Los Angeles, CA 90007

R. FINN and J. Milgram

Stanford University

Stanford, CA 94305

\section{ASSOCIATE EDITORS}
E. F. BeCKenbach
B. H. NeumanN
F. WOLF
K. YoshidA

\section{SUPPORTING INSTITUTIONS}

\author{
UNIVERSITY OF BRITISH COLUMBIA \\ CALIFORNIA INSTITUTE OF TECHNOLOGY \\ UNIVERSITY OF CALIFORNIA \\ MONTANA STATE UNIVERSITY \\ UNIVERSITY OF NEVADA, RENO \\ NEW MEXICO STATE UNIVERSITY \\ OREGON STATE UNIVERSITY \\ UNIVERSITY OF OREGON
}

\author{
UNIVERSITY OF SOUTHERN CALIFORNIA \\ STANFORD UNIVERSITY \\ UNIVERSITY OF HAWAII \\ UNIVERSITY OF TOKYO \\ UNIVERSITY OF UTAH \\ WASHINGTON STATE UNIVERSITY \\ UNIVERSITY OF WASHINGTON
}

The Supporting Institutions listed above contribute to the cost of publication of this Journal, but they are not owners or publishers and have no responsibility for its content or policies.

Mathematical papers intended for publication in the Pacific Journal of Mathematics should be in typed form or offset-reproduced, (not dittoed), double spaced with large margins. Please do not use built up fractions in the text of the manuscript. However, you may use them in the displayed equations. Underline Greek letters in red, German in green, and script in blue. The first paragraph or two must be capable of being used separately as a synopsis of the entire paper. Please propose a heading for the odd numbered pages of less than 35 characters. Manuscripts, in triplicate, may be sent to any one of the editors. Please classify according to the scheme of Math. Reviews, Index to Vol. 39. Supply name and address of author to whom proofs should be sent. All other communications should be addressed to the managing editor, or Elaine Barth, University of California, Los Angeles, California, 90024.

50 reprints to each author are provided free for each article, only if page charges have been substantially paid. Additional copies may be obtained at cost in multiples of 50 .

The Pacific Journal of Mathematics is issued monthly as of January 1966. Regular subscription rate: $\$ 84.00$ a year $(6$ Vols., 12 issues). Special rato: $\$ 42.00$ a year to individual members of supporting institutions.

Subscriptions, orders for numbers issued in the last three calendar years, and changes of address shoud be sent to Pacific Journal of Mathematics, P.O. Box 969, Carmel Valley, CA 93924, U.S.A Old back numbers obtainable from Kraus Periodicals Co., Route 100, Millwood, NY 10546.

\section{PUBLISHED BY PACIFIC JOURNAL OF MATHEMATICS, A NON-PROFIT CORPORATION}

Printed at Kokusai Bunken Insatsusha (International Academic Printing Co., Ltd.). 8-8, 3-chome, Takadanobaba, Shinjuku-ku, Tokyo 160, Japan. 


\section{Pacific Journal of Mathematics}

\section{Vol. 86, No. 2 December, 1980}

Graham Donald Allen, David Alan Legg and Joseph Dinneen Ward, Hermitian

liftings in Orlicz sequence spaces ............................... 379

George Bachman and Alan Sultan, On regular extensions of measures ........ 389

Bruce Alan Barnes, Representations Naimark-related to $*$-representations; a

correction: "When is a representation of a Banach $*$-algebra

Naimark-related to a $*$-representation?" ........................ 397

Earl Robert Berkson, One-parameter semigroups of isometries into $H^{p} \ldots \ldots .403$

M. Brodmann, Piecewise catenarian and going between rings ............ 415

Joe Peter Buhler, A note on tamely ramified polynomials ............... 421

William Lee Bynum, Normal structure coefficients for Banach spaces ........ 427

Lung O. Chung, Biharmonic and polyharmonic principal functions ......... 437

Vladimir Drobot and S. McDonald, Approximation properties of polynomials

with bounded integer coefficients .............................

Giora Dula and Elyahu Katz, Recursion formulas for the homology of

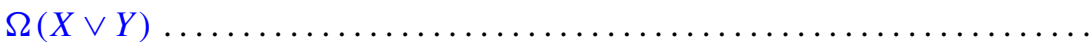

John A. Ernest, The computation of the generalized spectrum of certain Toeplitz operators ...................................... 463

Kenneth R. Goodearl and Thomas Benny Rushing, Direct limit groups and the

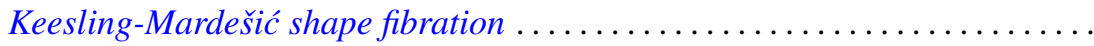

Raymond Heitmann and Stephen Joseph McAdam, Good chains with bad contractions

Patricia Jones and Steve Chong Hong Ligh, Finite hereditary near-ring-semigroups .

Yoshikazu Katayama, Isomorphisms of the Fourier algebras in crossed

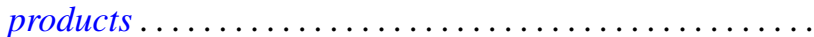

Meir Katchalski and Andrew Chiang-Fung Liu, Symmetric twins and common transversals. .

Mohammad Ahmad Khan, Chain conditions on subgroups of LCA groups ....

Helmut Kröger, Padé approximants on Banach space operator equations ...

Gabriel Michael Miller Obi, An algebraic extension of the Lax-Milgram theorem . .

S. G. Pandit, Differential systems with impulsive perturbation .

Richard Pell, Support point functions and the Loewner variation ...

J. Hyam Rubinstein, Dehn's lemma and handle decompositions of some

4-manifolds

James Eugene Shirey, On the theorem of Helley concerning finite-dimensional subspaces of a dual space.

Oved Shisha, Tchebycheff systems and best partial bases.... 